\title{
ALEMÃO PARA COPA
}

Kátia Murata $^{1}$

Tendo em vista a Copa do Mundo 2006, o CELIN ofereceu no mês de junho curso de Alemão diferenciado para alunos interessados em ampliar o conhecimento sobre a língua e cultura germânica.

O fato de o evento futebolístico ter ocorrido na Alemanha despertou o interesse pelo velho mundo e por seu vocabulário específico constante agora na fala de muitas pessoas.

A Unidade Temática relacionada ao tema Futebol foi criada em 2005 na matéria Didática, ministrada pelo Professor Henrique Janzen na UFPR. Surgiu, então, o curso com a possibilidade de colocá-la em prática e assim verificar sua eficácia. A elaboração foi uma parceria da aluna de letras Kátia Aiko Murata, com o intercambista do projeto UNIBRAL, Paul Voerkel, vindo da Universidade de Leipzig e foi apresentada pelos autores como projeto no início deste ano no Congresso Internacional da Associação Latino-americana de Estudos Germanísticos (ALEG) realizado em Havana, Cuba.

E por que o tema Futebol? A escolha decorreu de dois pressupostos: o da Abordagem Intercultural, cuja proposta é de ensino de língua estrangeira a partir do universo do aluno; o da Abordagem Comunicativa, visando desenvolver a capacidade de interação do aluno com a língua aprendida. Uma vez que o futebol é apreciado tanto por brasileiros, quanto por alemães - assim como também pela maioria das nacionalidades, é um vocabulário que está interiorizado nas pessoas. Por mais que a pessoa não goste deste esporte, quem é que não sabe o que é um escanteio ou um pênalti? Ou que o time é composto de onze jogadores e que o objetivo do jogo é “balançar a rede do gol”?

A unidade temática foi elaborada com a intenção de o aluno vivenciar situações diversas. Inicia-se por uma visão geral da Alemanha e das cidades onde aconteceriam os jogos; navega-se pelo site oficial da Copa; supõe-se como seriam preenchidas as tabelas das oitavas e quartas de final; visita-se virtualmente os estádios para conhecer e ativar o vocabulário utilizado durante um jogo. Por fim, há o contato com entrevistas e comentários após um jogo. Para tanto seria necessário o aluno já possuir um conhecimento prévio do idioma, no mínimo 3 semestres, suficiente para ser hábil a discutir o tema.

\footnotetext{
${ }^{1}$ Kátia Murata é formada em Letras Alemão e atualmente é professora no Centro de Línguas e Interculturalidade da Universidade Federal do Paraná.
} 
Entretanto, a prática do curso foi diferente do planejado, pois curiosamente a procura foi de pessoas, cujo conhecimento de alemão variava de dois a nove meses. Por isso, a unidade foi adaptada para este público. Não foram possíveis as esperadas discussões na língua estrangeira, mas procurou-se mesmo assim ir ao encontro dos pressupostos teóricos que basearam a elaboração do trabalho com as ferramentas possíveis.

\section{ABORDAGEM INTERCULTURAL: PARTIR DO UNIVERSO DO ALUNO:}

O que o aluno já conhecia da Alemanha? Devido à proximidade da realização da Copa do Mundo, os meios de comunicação já começavam a mostrar muitas coisas sobre a Alemanha e de cada cidade onde os jogos aconteceriam. Com a utilização da Internet, os alunos descobriram mais informações e, contrastaram-nas com a realidade próxima a eles. Partindo do pressuposto de que "o aprendiz não é convidado a despir-se de suas características culturais e assumir ou assimilar novas regras de conduta e pensamento.” (MEIRELES, S.M. p.159). Por exemplo, ao trabalhar com o tamanho e número de habitantes de cada cidade foi muito mais concreto comparar essas dimensões com aquelas que eles já conhecem. "Berlin ist zweimal großer und hat 2,5mal mehr Einwohner als Porto Alegre،2 tem muito mais sentido para o aluno que simplesmente: "Berlin ist $891,182 \mathrm{~km}^{2}$ gro $\beta$ und hat 3.396.990 Einwohner”3. Seria muito abstrato falarmos somente de números. Dessa maneira valorizou-se também o ambiente e a cultura do aluno.

Outra situação: quais os times participantes da Copa? Em que continente localizase cada um desses países? Os nomes dos países em alemão se aproximam bastante do português. Essa semelhança com a língua materna contribuiu para a compreensão do tema e mais uma vez partimos do conhecimento prévio do aluno. "Elfenbeinküste liegt in Afrika und spielt gegen Serbien und Montenegro am 21. Juni in München“. ${ }^{4}$ Não precisou dizer mais nada. Os alunos já sabiam de qual time estava sendo falado. Daí para montar a tabela de jogos, quem joga contra quem, onde e quando foi fácil. Muitos já sabiam de alguns jogos e, mesmo com pouco vocabulário, a animação por supor quem ganharia ou perderia foi grande. E, só o fato de apresentar algumas funções comunicativas e lá estavam os alunos opinando

\footnotetext{
${ }^{2}$ Berlin é duas vezes maior e tem 2,5 vezes mais habitantes que Porto Alegre.

${ }^{3}$ Berlin tem 891,182 $\mathrm{Km}^{2}$ e 3.396 .900 habitantes

${ }^{4}$ Costa do Marfim fica na Africa e joga contra Serbia e Montenegro dia 21 de junho em Munique.
} 
"ich denke, Kroatien gewinnt...ich glaube nicht. Ich denke Kroatien verliert. Warum? Die Mannschaft ist zu schwach, der Trainer ist gut usw“. ${ }^{5}$

$\mathrm{Na}$ abordagem intercultural, a valorização da cultura do aluno como igualmente legitimada em relação à cultura da língua estrangeira é segundo Selma Martins Meireles é o que há de mais importante, pois “estabelecer uma relação (dialética) entre a própria cultura e a cultura alheia, no sentido de diálogo cultural, é um dos objetivos básicos da Germanística Intercultural.” (JANZEN, H.E. p. 140, 2002).

\section{ABORDAGEM COMUNICATIVA: DESENVOLVIMENTO DA CAPACIDADE DO ALUNO DE INTERAGIR NA LÍNGUA APRENDIDA:}

Diferente da abordagem intercultural, a comunicativa, segundo MEIRELES(2002), visa principalmente a capacitar o aluno a orientar-se e a integrar-se no cotidiano estrangeiro. O sistema lingüístico é visto como um instrumento de interação humana, sendo que as formas e estruturas lingüísticas devem ser transmitidas em seu significado funcional. "Ela é voltada para a comunicação e a pragmática privilegiando o uso da língua estrangeira, concebendo-a como um meio de comunicação em situações cotidianas, principalmente no trabalho e no lazer (NEUNER, 1986, 9.13).”

Na hora do jogo é que os ânimos esquentam! No momento em que a bola “balança a rede”, quem não vibra ao gritar: GGGGGGGGOOOOOLLLLLL!!! Como não seria possível jogarmos uma partida de futebol real dentro da sala de aula, por sugestão de um aluno, jogamos futebol de botão. Primeiramente as expressões foram trabalhadas com fotos para que os alunos as conhecessem e fomos ao jogo: “Brasilien gegen Deutschland. Pfosten! Foul! Jetzt! Das war knapp! Es gilt nicht! Wo ist der Ball? Ecke! Gehalten!"’6 .Pelo pouco conhecimento prévio que os participantes do curso tinham, não se poderia esperar construções gramaticais complexas. Mas durante 20 minutos de jogo, as expressões foram fazendo cada vez mais sentido para eles e ao final vinham naturalmente. Porém, devido à falta de prática de todos no futebol de botão, “TOR TOR TOOOOOOOOR”7 não saiu e o jogo acabou "null zu

\footnotetext{
${ }^{5}$ eu acho que a Croácia ganha...eu não acredito. Eu acho que a Croácia perde. Por quê? O time é muito fraco, o treinador é bom etc.

${ }^{6}$ Brasil contra Alemanha. "na trave! falta! Agora! Essa foi por pouco! Não vale! Cadê a bola? Escanteio! Defendido!

${ }^{7}$ GGGGGOOOOOOLLLLLLL!!!
} 
null”. . Mas tudo bem. Era só um jogo de futebol de botão, com jogadores nada treinados. O importante é que a Copa estava para iniciar e todos estavam preparados a gritar: "Brasilien vor, noch ein Tor!",9

\section{REFERÊNCIAS BIBLIOGRÁFICAS:}

MEIRELES, S.M. Língua estrangeira e autonomia: um exemplo a partir do ensino de alemão no contexto brasileiro. Educar, Curitiba, n.20, p. 149-164. 2002. Editora UFPR.

JANZEN, H.E. Interculturalidade e o ensino de alemão como língua estrangeira. Educar, Curitiba, n. 20, p. 137-147. 2002. Editora UFPR.

HUNEKE, Hans-Werner; STEINIG, Wolfgang. Deutsch als Fremdsprache. Eine Einführung. Berlin, p.170-177. 2005. Erich Schmidt Verlag.

\footnotetext{
${ }^{8}$ zero a zero

${ }^{9}$ Brasil na frente, mais um gol!
} 